\title{
MAsCulinities: The Field OF KNOWLEdGe
}

\author{
RAEWYN CONNELL
}

\begin{abstract}
In the last twenty-five years a body of international research on masculinities has consolidated and important conclusions of this research are as follows: there are multiple masculinities, there are hierarchies of masculinities, often defining a hegemonic pattern for a given society; masculinities are collective as well as individual; masculinities are actively constructed in social life; masculinities are internally complex; masculinities change throughout history. Certain masculinities operate in global, not just local, arenas. We can trace this historically through the phases of imperialism, colonialism, de-colonization, and contemporary globalization. New masculinities are also emerging in global business. At the same time, movements that aim to reform masculinities have developed in many countries. While many men resist change because of the dividend they get from patriarchal gender systems, there are also important motives for men to change their gender practices. The article argues that such changes or reforms are most likely to be successful when they emphasize social justice as well as gender diversity or de-gendering.
\end{abstract}

\section{Conceptualizing gender and masculinity}

In the last four decades, there has been a huge growth of debate and investigation on men as gendered beings, on questions about masculinity. The main impulse for this was the women's movement and its problematization of gender. Most feminist research has, for good reasons, focused on the lives of women. But gender is inherently relational. Even if our understanding of gender is no more than sex differences, there must always be two terms in a difference. 
A closer look at gender shows the reality involves much more complex patterns than simple difference. Gender is also about relationships of desire and power, and these must be examined from both sides. In understanding gender inequalities it is essential to research the more privileged group as well as the less privileged. For good reasons, then, there has been a marked growth in gender-informed research about men and masculinities, ${ }^{1}$ which now comes from every region of the world. ${ }^{2}$

This project requires more than simply an examination of men as a statistical category. It requires an examination of men's gender practices; the ways the gender order defines, positions, empowers, and constrains men; and the consequences of those definitions in culture and in the lives of women. In short, it is necessary to study masculinity.

By "masculinity" I mean the pattern or configuration of social practices linked to the position of men in the gender order, and socially distinguished from practices linked to the position of women. Masculinity is not a pre-social category. Masculinity constantly refers to male bodies (sometimes symbolically and indirectly), but is not determined by male biology. One can, therefore, speak of masculine women, and feminine men; of gender ambivalences and contradictions. This is, indeed, an important theme in gender analysis, since the days of Sigmund Freud.

An understanding of masculinity starts with the gender orders in which masculinities are defined. There are different perspectives on this question. Perhaps the most widespread in the social sciences and in professional practices adopts the concept of "sex roles". Sex role theory explains gender patterns by appealing to the social customs that define proper behavior for women and for men.

${ }^{1}$ See Handbook of Studies on Men and Masculinities, eds Michael Kimmel, Jeff Hearn and Raewyn Connell, Thousand Oaks, CA: Sage, 2005.

${ }^{2}$ See, for example, From Boys to Men: Social Constructions of Men in Contemporary Society, eds Tamara Shefer et al., Lansdowne, South Africa: UCT Press, 2007; Masculinidades y Globalización: Trabajo y Vida Privada, Familias y Sexualidades, ed. José Olavarría, Santiago, Chile: Red de Masculinidad/es, Universidad Academia de Humanismo Cristiano (UAHC) and Centro de Estudios para el Desarrollo de la Mujer (CEDEM), 2009; Xingkui Zhang, Studies of Men and Masculinities in Contemporary China, PhD thesis, Faculty of Education and Social Work, University of Sydney, 2010. 
Applied to men, the sex role approach emphasizes the way expectations about proper masculine behavior are conveyed to boys as they grow up, by parents, schools, mass media, and peer groups. This theory emphasizes the role models provided by sportsmen, military heroes, etc.; and the social sanctions (from mild disapproval to violence) that are applied to boys and men who do not live up to the role norms. This is a plausible approach to some issues about masculinity. But sex role theory has serious intellectual weaknesses. ${ }^{3}$ It gives no grasp on issues of power, violence, or material inequality. It misses the complexities within femininity and masculinity, and it offers very limited strategies of change.

Another widely used model of gender, which I call "categorical theory", treats women and men as pre-formed categories. In categorical thinking about gender, the focus is on some relation between the pre-determined categories - most often a relation of difference or inequality. This is, for instance, the logical structure underlying most discussions of gender equity policy, such as "Equal Opportunity" statistics contrasting men's employment with women's employment.

Compared with sex role theory, this approach more readily addresses issues of power. But categorical gender research too has difficulty grasping the complexities of gender, such as gendered violence within either of the two main categories. The categorical approach leaves little space for the interplay of gender with class and race, and misses such issues as the importance of unionism for working-class women, or community organizing for indigenous women.

Categorical thinking, in the form of gender essentialism, was the principal target of deconstructive gender theory and post-structuralist approaches that locate gender in the realm of discourse. This became the most popular approach to gender in the Anglophone academic world of the global North, especially in fields such as the humanities that normally deal with texts, documents and discourse. ${ }^{4}$ A large body of research now examines the discursive construction of masculinities in literature, mass media, and other cultural forms.

This approach, enormously productive in some fields, has little grip on others. It is not well suited to political economy, research on institutions, or questions of social dynamics, including most of the

\footnotetext{
${ }^{3}$ See Raewyn Connell, Gender and Power, Cambridge: Polity, 1987.

${ }^{4}$ See Rachel Alsop, Annette Fitzsimons and Kathleen Lennon, Theorizing Gender: An Introduction, Cambridge: Polity, 2002.
} 
urgent problems of policy and practice that concern masculinity in the developing world..$^{5}$ Researchers prioritizing fields such as these tend to emphasize that gender issues always concern a structure of social relations.

In a structural approach, gender is understood as a way in which social practice is ordered. In gender processes, the everyday conduct of life is organized in relation to a reproductive arena, defined by the bodily structures and processes of human reproduction. This arena includes sexual arousal and intercourse; childbirth and infant-care; bodily sex difference, and similarity. I call this a "reproductive arena" rather than a "biological basis" because biology does not determine what happens. Rather, bodies are participants in a historical process as both agents and objects of practice. ${ }^{6}$

Social practice is creative and inventive, but not formless. As social beings, we act in response to particular situations, within definite structures of social relations. Gender relations, the relations among people and groups organized through the reproductive arena, form one of the major structures of all documented societies. Practice that relates to this structure, generated as people and groups grapple with their historical situations, does not consist of isolated acts. Actions are configured in larger units, and when we speak of "masculinity" and "femininity" we are naming configurations of gender practice. Seen in terms of change through time, masculinities and femininities are best understood as gender projects, dynamic arrangements of social practice through time, in which we make ourselves and are made as particular kinds of human beings. ${ }^{7}$

Understanding gender as a fundamentally historical phenomenon means that we must understand gender, and masculinity, in their connection with the most important historical change in modern world history - the process of colonial expansion, conquest, resistance, and the subsequent neocolonialism and postcolonial globalization. It is increasingly recognized that these are crucial contexts for the making of masculinities, both in the colonizing powers and among the colo-

\footnotetext{
${ }^{5}$ See Men and Development: Politicizing Masculinities, eds Andrea Cornwall, Jerker Edström and Alan Greig, London: Zed Books, 2011.

${ }^{6}$ See Raewyn Connell and Rebecca Pearse, Gender: In World Perspective, 3rd edn, Cambridge: Polity, 2014.

${ }^{7}$ Raewyn Connell, Masculinities, 2nd edn, Cambridge: Polity, 2005.
} 
nized, and among the groups and movements and social struggles of the postcolonial world.

\section{Crucial research findings}

Historians and anthropologists have shown that there is no one pattern of masculinity that is found everywhere. Different cultures, and different periods of history, construct masculinity differently. Some cultures regard homosexual sex as incompatible with true masculinity; others think no one can be a real man without having had homosexual relationships. Some cultures make heroes of soldiers, and regard violence as the ultimate test of masculinity; others look at soldiering with disdain and regard violence as contemptible. The masculinities of east Asia, for instance, have a different history and now exist in different configurations from those of, say, North America. ${ }^{9}$

It follows that in large-scale societies there are likely to be multiple definitions of masculinity. Sociological research shows this to be true, with differences of class, ethnicity and generation. Equally important, more than one kind of masculinity can be found within a given cultural setting. Within any workplace, neighborhood or peer group, there are likely to be different understandings of masculinity and different ways of "doing" masculinity. Quite complex negotiations of the meanings of masculinity occur in the flow of everyday life, as shown in ethnographic research. ${ }^{10}$

There are definite relationships between different patterns of masculinity. Typically, some masculinities are more honored than others. Some may be actively dishonored, for example homosexual masculinities in modern Western culture. Some are socially marginalized, for example the masculinities of disempowered ethnic minorities. Some are exemplary, taken as symbolizing admired traits, for example the masculinities of sporting heroes.

The form of masculinity which is culturally dominant in a given setting is commonly called "hegemonic masculinity". "The idea of

${ }^{8}$ See Changing Men in Southern Africa, ed. Robert Morrell, London: Zed Books, 2001.

${ }^{9}$ See Kam Louie and Morris Low, Asian Masculinities: The Meaning and Practice of Manhood in China and Japan, London: Routledge, 2003.

${ }^{10}$ See Matthew Gutmann, The Meanings of Macho: Being a Man in Mexico City, Berkeley, CA: University of California Press, 1996.

${ }^{11}$ For debate on this concept, see Raewyn Connell and James W. Messerschmidt, "Hegemonic Masculinity: Rethinking the Concept", Gender and Society, XIX/6 (De- 
hegemony signals a position of cultural authority and leadership, not total dominance; other forms of masculinity persist alongside. The hegemonic form need not be the most common form of masculinity. A hegemonic masculinity is, however, likely to be highly visible. Hegemonic masculinity is hegemonic not just in relation to other masculinities, but in relation to the gender order as a whole. It is an expression of the privilege men collectively have over women. The hierarchy of masculinities is an expression of the unequal shares in that privilege held by different groups of men.

The gender structures of a society define particular patterns of conduct as "masculine" and others as "feminine". At one level, these patterns characterize individuals. Thus we say that a particular man (or woman) is masculine, or behaves in a masculine way. But these patterns also exist at the collective level. Masculinities are defined and sustained in institutions such as corporations, armies, and governments or schools. Masculinities are defined collectively in the workplace, as shown in industrial research; and in informal groups like street gangs, as shown in criminological research.

Masculinity also exists impersonally in culture. Video games, for instance, not only circulate stereotyped images of violent masculinity. They require the player to enact this masculinity (symbolically) in order to play the game at all. Sociological research on sport has shown how an aggressive masculinity is created organizationally by the structure of organized sport, by its pattern of competition, its system of training, and its steep hierarchy of levels and rewards. ${ }^{12}$ Images of this masculinity are circulated on an enormous scale by sports media, though most individuals fit very imperfectly into the cultural slots thus created.

Masculinities do not exist prior to social behavior, either as bodily states or fixed personalities. Rather, masculinities come into existence as people act. They are accomplished in everyday conduct or organizational life, as patterns of social practice. Close-focus research has

cember 2005), 829-59; Richard Howson, Challenging Hegemonic Masculinity, London: Routledge, 2006; Christine Beasley, "Problematizing Contemporary Men/Masculinities Theorizing: The Contribution of Raewyn Connell and Conceptual-Terminological Tensions Today", British Journal of Sociology, LXIII/4 (December 2012), 747-65.

${ }^{12}$ See Michael A. Messner, Out of Play: Critical Essays on Gender and Sport, Albany: State University of New York Press, 2007. 
shown how we "do gender" in everyday life. ${ }^{13}$ A similar insight has thrown new light on the link between masculinity and crime. This is not a product of a fixed masculine character being expressed through crime. Rather, the link results from a variety of men from impoverished youth gangs on the street to white-collar criminals at the computer using crime as a resource to construct particular masculinities. ${ }^{14}$

A great deal of effort can go into the making of masculinities, hegemonic or non-hegemonic. Research on homosexual men's lives shows that for these men too, identity and relationships involve a complex and sustained effort of construction. ${ }^{15}$ One reason why masculinities are not fixed is that they are not simple, homogenous patterns. Close-focus research on gender often reveals contradictory desires and logics. A man's active heterosexuality may exist as a thin emotional layer concealing a deeper homosexual desire. A boy's identification with men may co-exist or struggle with identifications with women. The public enactment of an exemplary masculinity may covertly require actions which undermine it. The complexity of desires, emotions or possibilities may not be obvious at first glance. But the issue is important, because these complexities are sources of tension and change in gender patterns. ${ }^{16}$

From the fact that different masculinities exist in different cultures and historical epochs, we can deduce that masculinities are able to change. To speak of the "dynamics" of masculinity is to acknowledge that particular masculinities are composed, historically, and may also be de-composed, contested, and replaced. There is an active politics of gender in everyday life. Sometimes it finds public expression, more often it is local and limited. But there is always a process of contestation and change; and in some cases this becomes conscious and deliberate. This has happened, for instance, in the "men's movements" of North America in the 1980s and 1990s. ${ }^{17}$

\footnotetext{
${ }^{13}$ See Doing Gender, Doing Difference: Inequality, Power, and Institutional Change, eds Sarah Fenstermaker and Candace West, New York: Routledge, 2002.

${ }^{14}$ See James W. Messerschmidt, Masculinities and Crime: Critique and Reconceptualization of Theory, Lanham, MD: Rowman and Littlefield, 1993.

${ }^{15}$ See Gary Wayne Dowsett, Practicing Desire: Homosexual Sex in the Era of AIDS, Stanford, CA: Stanford University Press, 1996.

${ }^{16}$ See Connell, Masculinities.

${ }^{17}$ See Michael A. Messner, The Politics of Masculinities: Men in Movements, Thousand Oaks, CA: Sage, 1997.
} 


\section{Masculinities and world arenas}

The social sciences and humanities have given increasing attention to globalization, and the field of gender studies is no exception. ${ }^{18}$ To understand the relationship between globalization and the formation of masculinities we have to start with the history of colonialism and the structures of empire. Colonization itself was mostly carried out by a workforce of men, and had a profound effect on gender orders among the colonized. As the imperial social order stabilized, it created a hierarchy of masculinities, as it created a hierarchy of communities and races. The colonizers distinguished "more manly" from "less manly" groups among their subjects. In British India, for instance, Bengali men were supposed effeminate, while Pathans and Sikhs were regarded as strong and warlike.

At the same time, the emerging imagery of gender difference in European culture provided general symbols of superiority and inferiority. In the colonizer's mind, the conqueror was virile, while the colonized were dirty and sexualized, or effeminate, or childlike. In many colonial situations indigenous men were called "boys" by the colonizers. In the late nineteenth century, racial barriers in colonial societies were hardening rather than weakening, and gender ideology tended to fuse with racism in forms that the twentieth century has never untangled.

The power relations of empire meant that indigenous gender orders were generally under pressure from the colonizers, rather than the other way around. But the colonizers too might change. The barriers of late colonial racism were not only to prevent pollution from below, but also to forestall "going native", a well-recognized possibility. The pressures, opportunities, and profits of empire might also create changes in gender arrangements among the colonizers. For instance the work of married women changed in households with a large supply of indigenous workers as domestic servants. Empire might also affect the gender order of the metropole itself: through changing gender ideologies, divisions of labor, and the nature of the metropolitan state. For instance, empire figured prominently as a source of masculine imagery in Britain, in the Boy Scouts, and in the cult of "Lawrence of Arabia" as a national hero.

${ }^{18}$ See Esther Ngan-ling Chow, "Gender Matters: Studying Globalization and Social Change in the 21st Century", International Sociology, XVIII/3 (September 2003), 443-60. 
The world of empire created two very different settings for the modernization of masculinities. In the periphery, the forcible restructuring of economies and workforces tended to individualize social relations and rationalize economies. The specific form of masculinity might be local; for instance the Japanese "salary man", a social type first recognized in the first decade of the twentieth century, was specific to the Japanese context of large, stable industrial conglomerates. The result generally was middle-class masculinities defined around economic action and increasingly adapted to emerging market economies. But in recent years this pattern has come under increasing pressure and demands for change. ${ }^{19}$

In the metropole, the accumulation of wealth made possible a specialization of leadership in the dominant classes. Struggles for hegemony followed, in which masculinities organized around domination or violence were split from masculinities organized around expertise. Political contests between Fascism and liberalism, between "hardliners" and "soft-liners", showed these divisions. In the context of both first-wave and second-wave feminism, reform movements appeared, including the temperance movement, companionate marriage, and homosexual rights movements, leading eventually to the pursuit of androgyny in "men's liberation" in the Seventies. Not all reconstructions of masculinity, however, emphasized tolerance. The vehement masculinity politics of fascism, for instance, emphasized both dominance and difference, ${ }^{20}$ a pattern still found in contemporary racist movements.

The process of de-colonization disrupted the gender hierarchies of the colonial order. Some activists and theorists of liberation struggles celebrated masculine violence, as a necessary response to colonial violence and emasculation: women in liberation struggles were less impressed. ${ }^{21}$ However one evaluates the process, one of the consequences of de-colonization was further disruption of community-

\footnotetext{
${ }^{19}$ See Men and Masculinities in Contemporary Japan: Dislocating the Salaryman Doxa, eds James E. Roberson and Nobue Suzuki, London: Routledge, 2003.

${ }^{20}$ See Männlichkeitskonstruktionen im Nationalsozialismus, eds Anette Dietrich and Ljiljana Heise, Frankfurt am Main: Peter Lang, 2013.

${ }^{21}$ See Amina Mama, "Sheroes and Villains: Conceptualizing Colonial and Contemporary Violence against Women in Africa", in Feminist Genealogies, Colonial Legacies, Democratic Futures, eds M. Jacqui Alexander and Chandra Talpade Mohanty, New York: Routledge, 1997, 46-62.
} 
based gender orders, and another step in the re-orientation of masculinities towards national and international contexts.

With the collapse of Soviet Communism, the decline of postcolonial Socialism, and the ascendancy of the new right in Europe and North America, world politics is more and more organized around the needs of transnational capital and the creation of global markets. The neo-liberal agenda has little to say, explicitly, about gender. It speaks a gender-neutral language of "markets", "individuals", and "choice". But the world in which neo-liberalism is ascendant is still a gendered world, and neo-liberalism has an implicit gender politics.

The individual of neo-liberal theory has the attributes and interests of a male entrepreneur. The attack on the welfare state usually weakens the position of women, while the increasingly unregulated power of transnational corporations places strategic power in the hands of particular groups of men. It is not surprising, then, that the installation of capitalism in Eastern Europe and the former Soviet Union has been accompanied by a reassertion of dominating masculinities, a trend that has been turned to advantage by Vladimir Putin.

Among the business executives who operate in global markets, the owners of big capital, and the political executives who interact (and in many contexts merge) with them, we are likely to see the hegemonic masculinities of contemporary globalization. Among the very rich, a defensive masculinity, produced by a conscious toughening education and marked by distrust, seems to prevail. ${ }^{22}$ Among executives, we are more likely to see a masculinity marked by increasing egocentrism, conditional loyalties (even to the corporation), and a declining sense of responsibility for others, seen in neoliberal attacks on welfare recipients and the public sector. Management textbooks portray the manager as a person with no permanent commitments, except (in effect) to the idea of accumulation itself. Contemporary corporate masculinity differs from traditional bourgeois masculinity by its increasingly libertarian sexuality, with a growing tendency to commodify relations with women. In many parts of the world there is a well-developed highlevel prostitution industry catering for international businessmen. Corporate masculinity does not require bodily force, since the wealth on which it rests is accumulated by impersonal, institutional means. But corporations increasingly use the exemplary bodies of elite

${ }^{22}$ See Mike Donaldson and Scott Poynting, Ruling Class Men: Money, Sex, Power, Bern: Peter Lang, 2007. 
sportsmen as a marketing tool (note the phenomenal growth of the corporate sponsorship of sport), and indirectly as a means of legitimation for the whole gender order.

\section{Changing masculinities}

In the days of the small but active Men's Liberation movement in the 1970 s, it was assumed that feminism was good for men, because men too suffered from rigid sex roles. As women broke out of their sex role, men would be enabled to break out of theirs, and would have fuller, better, and healthier lives as a result.

Few men actually followed this path, at least in the short term. Men's dominant position in the gender order has a material pay-off, which I call the "patriarchal dividend" for men, and this dividend is not withering away. The gender segregation of the workforce in the rich countries has declined little in recent years. Men's representation in parliaments worldwide has risen, not fallen, over the last five years. As corporations have gone multinational under the aegis of transnational business masculinity they have increasingly escaped the national-level political structures through which women press for gender equality. International industries such as garment manufacturing and microprocessor assembly are arenas of rampant sexism. Violence against women has not measurably declined.

What might change men's attachment to a patriarchal society? There are several possibilities. First, the appeal of justice itself; men can support change simply because they believe it is right. Statements of human rights, however often they are evaded, do have some force in the long run. Second, though men in general gain the patriarchal dividend, specific groups of men gain very little of it. For instance, working-class youth, economically dispossessed by structural unemployment, may gain no economic advantage at all over the women in their communities. Other groups of men pay a price, alongside women, for the maintenance of an unequal gender order. Gay men are frequently made targets of prejudice and violence, and effeminate men are constantly abused. Indigenous men often experience extremely high rates of unemployment and imprisonment.

Third, men have interests which are not purely egotistic. Most men have relational interests that they share with particular women. Men's lives frequently involve dense networks of relationships with women: with mothers, wives, partners, sisters, daughters, aunts, grandmothers, friends, workmates, and neighbors. Each of these relationships can be 
the basis for men's relational interest in reform. For instance, a father has an interest in his daughter being free of sexual harassment at school, in her having access to education and training, in her growing up a confident and autonomous person.

Which of these interests is actually pursued by particular men is a matter of politics in the quite familiar sense, of organizing in the pursuit of programs. A complex terrain of masculinity politics has emerged in the last generation, which as Messner observes, involves conflicting agendas of change. ${ }^{23}$ It involves a variety of rhetorics and political strategies, visible in comparative studies. ${ }^{24}$ In the Nordic countries, for instance, changes in state policy have been crucial in masculinity politics, such as the funding of paternity leave for new fathers, the famous "father's month". ${ }^{25}$ A crucial fact is that progressive masculinity politics, together with masculinity research, have now emerged in all regions of the world, from Latin America ${ }^{26}$ to south Asia. ${ }^{27}$

This has provided a basis for global initiatives. One of these was undertaken by UNESCO, an attempt to consolidate knowledge about masculinities, violence and peacemaking. ${ }^{28}$ A second was an initiative through the United Nations secretariat, leading to the first worldwide policy document about these issues, the Agreed Conclusions of the 2004 United Nations Commission on the Status of Women on "The Role of Men and Boys in Achieving Gender Equality". ${ }^{29}$ A third is the recent creation of a global network of NGOs and other agencies concerned with change among men, MenEngage.

${ }^{23}$ See Messner, The Politics of Masculinities.

${ }^{24}$ See Bob Pease and Keith Pringle, A Man's World? Changing Men's Practices in a Globalized World, London: Zed Books, 2006.

${ }^{25}$ See Oeystein Gullvag Holter, Can Men Do It? Men and Gender Equality - the Nordic Experience, Copenhagen: Nordic Council of Ministers, 2003.

${ }^{26}$ See Masculinidades y equidad de genero en America Latina, eds Teresa Valdés and José Olavarría, Santiago, Chile: FLACSO-Chile, United Nations Fund for Publication Activities (UNFPA), 1998.

27 See Reframing Masculinities: Narrating the Supportive Practices of Men, ed. Radhika Chopra, New Delhi: Orient Longman Private, 2007.

${ }^{28}$ Male Roles, Masculinities and Violence, eds Ingeborg Breines, R.W. Connell and Ingrid Eide, Paris: UNESCO, 2000.

29 James Lang, Alan Greig and Raewyn Connell, in collaboration with the Division for the Advancement of Women, "The Role of Men and Boys in Achieving Gender Equality", Women 2000 and Beyond series, New York: United Nations Division for the Advancement of Women / Department of Economic and Social Affairs, 2008: http.www.un.org/womenwatch/daw/w2000.html. 
Gender relations involve different spheres of practice, as well as different geographies, so there is an unavoidable complexity in gender politics. The days of simple solutions are long past. As reform agendas develop around the world, ${ }^{30}$ the field of knowledge will be extended and its value, already evident in scientific terms, will be tested more and more in practice. ${ }^{31}$

${ }^{30}$ See Chopra, Reframing Masculinities; Men and Gender Equality: Towards Progressive Policies, eds Jouni Varanka, Antti Närhinen and Reetta Siukola, Helsinki: Ministry of Social Affairs and Health, 2006; Lang, Greig and Connell, "The Role of Men and Boys in Achieving Gender Equality".

${ }^{31}$ This article draws on the framework proposed in my book Masculinities, and on my contribution, "Gender, Men and Masculinities", to Quality of Human Resources: Gender and Indigenous Peoples, ed. Eleanora Barbieri-Masini, Encyclopedia of Life Support Systems, I, UNESCO, 2009, 140-55. I am grateful to the many people who have offered criticisms and extensions to the argument of Masculinities; the real development of social-scientific knowledge is a collective work. 